JURNAL ILMIAH MANAJEMEN BISNIS DAN INOVASI UNIVERSITAS SAM RATULANGI

\title{
THE INFLUENCE OF COUNTRY-OF-ORIGIN IMAGE, BRAND IMAGE, AND BRAND EVALUATION ON PURCHASE INTENTION TOWARDS NIKE BRAND IN JABODETABEK
}

\author{
As Syifa Mujahidah, Pauline Henriette Pattyranie Tan
}

Universitas Pelita Harapan

A R T I C L E I N F O

Keywords: Country of Origin

Image, Brand Image, Brand

Evaluation, Purchase Intention
Abstract: The athletic footwear industry is growing rapidly in both global and domestic markets, and one of the major global brand players is Nike, which holds the largest market share in the world, followed by Adidas. However, this did not happen in the Indonesian market where Nike was beaten by Adidas to take second place. The difference in this condition is interesting to investigate further about the factors that can influence the buying interest of Indonesian consumers towards the Nike brand, especially in the Greater Jakarta area. Therefore, further research was conducted to determine whether the image of the country of origin, brand image, and brand evaluation could influence purchase interest, through data from 220 respondents who live in Jabodetabek. The hypothesis tested using PLS-SEM shows that all variables have a positive correlation in influencing consumer purchase intentions of the Nike brand, except for the country of origin. The findings in this study will be of great benefit to consumers, marketers and researchers in the future, especially those involved directly and indirectly with the United States and the Nike brand.

Abstrak: Industri alas kaki atletik berkembang pesat baik di pasar global maupun pasar domestik, dan salah satu pemain merek global utama adalah Nike, yang memegang pangsa pasar terbesar di dunia, diikuti oleh Adidas. Namun hal tersebut tidak terjadi di pasar Indonesia dimana Nike dikalahkan oleh Adidas untuk menempati posisi kedua. Perbedaan kondisi ini menarik untuk diteliti lebih jauh mengenai faktor-faktor yang dapat mempengaruhi minat beli konsumen Indonesia terhadap merek Nike, khususnya di wilayah Jabodetabek. Oleh karena itu, penelitian lebih lanjut dilakukan untuk mengetahui apakah citra negara asal, citra merek, dan evaluasi merek dapat mempengaruhi minat beli, melalui data dari 220 responden yang berdomisili di Jabodetabek. Hipotesis yang diuji menggunakan PLS-SEM menunjukkan bahwa semua variabel memiliki korelasi positif dalam mempengaruhi niat beli konsumen atas merek Nike, kecuali negara asal. Temuan dalam studi ini akan sangat bermanfaat bagi konsumen, pemasar, dan peneliti di masa mendatang, terutama yang terlibat langsung dan tidak langsung dengan Amerika Serikat dan merek Nike. 


\section{INTRODUCTION}

The era of globalization and liberalization of trade has made the international business activities become easier. Globalization and international business are interrelated as the commercial transactions, including sales, investment, and transportation between two or more countries. (Daniels et al., 2015). This has led to growth in several industries, including the sportswear industry. Sportwear is part of the retail industry with its main products are athletic clothing and footwear. The athletic footwear subindustry has a growing market. Increasing public awareness of health, led the footwear demand to increase. This industry has major players as Nike, Adidas, Puma, Reebok, Converse, Sketcher, New Balance, etc.

Nike holds the largest market share in the world, followed by Adidas. The statistical data shows that Nike has the highest footwear sales in the world market from 2016 to 2019 (Statista, 2020). On 2019, Nike's sales almost reach $\$ 25$ billion in the worldwide market. Nike has the strength in the athletic footwear sector for everyone from men, women, and children. According to a survey, $56 \%$ of people choose Nike as a "fitness brand" for sports and workout accessories (Statista, 2016 cited by Harrison, Accessed in 2020).

Nike is a multinational company from Germany that is well-known brands throughout the world. To survive as a major player and continue to increase its market share, Nike have to implement the right strategies and being competitive in the industry. But, according to Top Brand Award (2019), there's different condition in the Indonesian market. The data shows that Nike is on the second position which defeated by Adidas.

Indonesian consumers are faced with a choice between shoes products from local brands or the foreign one. Badan Pusat Statistik (BPS) noted that imports of sport shoes have the greatest rate of increase, which reached a value of US $\$ 60.4$ million in the January-April 2019 period, which increased in from the previous year of US $\$ 40.1$ million (Kusuma, 2019). According to designer Ali Charisma, around $60 \%$ of Indonesians choose foreign fashion brands then the domestic one (Yulistara, 2018).

With the increasing demand for imported products in the Indonesian market, the purpose of this research was to gain further study on how the country of origin influence the brand and become a factor in Indonesian consumer purchase intention. As it is known that every country has different social, cultural, political and legal systems and economic systems. Therefore, to be competitive in the international market, the company needs to look deeply in establishing a global marketing strategy that is by consumer behavior to provide value to these consumers (Keegan \& Green, 2013, p. 24).

Consumer behaviour is a study of consumer actions while looking for, buying, using, evaluating and disposing of products and services that are expected to satisfy their needs (Schiffman \& Wisenblit, 2015, p. 30). The purpose of studying consumer behaviour is to understand why and how consumers make their purchase decisions. Before into the purchase decisions stage, consumers will seek factors that can influence them to have an intention to purchase towards the product.

Then, is the Nike brand image in Indonesia is already good and can be a factor in consumer purchase intention. And the last, how consumers evaluate the Nike brand and is it can influence 
the consumer purchase intention towards Nike.

According to Azjen (2005 cited by Tulipa et al., 2015) intention is a will that is stored in the consumer's memory which in turn will lead to their actions, in this case, a trigger is needed to change the intention into action. Purchase intention is the main characteristic of consumer behaviour referred to as a customer's decision to buy a good or service (Dodds et al., 1991; Kim et al., 2011; Van der Heijden, 2003; Yaqoob, 2018, p. 34). Purchase intention is the willingness of consumers and the possibility to buy products and services in the future after the evaluation has been carried out (MacKenzie et al., 1986; Laroche \& Sadokierski, 1994; Panigara \& Ratnaningtyas, 2017).

Many previous researchers has conduct factors that can influence the consumers purchase intention both external and internal factors, as follows:

\section{Country of Origin Image and Brand Image}

Country of origin was first defined by Nagashima (1970, in Sharon Lew \& Zuraidah Sulaiman, 2014), namely the description, reputation and stereotypes of the products of a country that are built from product variables, national characteristics, economic background, politics, history and traditions. The influence of country of origin image on consumer perceptions of products has been a very broad study in International Marketing (Peterson and Jolibert, 1995; Leonidou et al., 1999; Shain et al., 2013; Erdogan, Senem, \& Onur, 2017). Country of origin image is the belief, idea, and impression that a person has about a country formed from associations and informational indications connected to a place (Herrero-Crespo, Gutierrez, Garcia-Salmones, 2016).

Country of origin is one of the variables considered to have a significant influence on brand image. This is evidenced by several studies that have been conducted by researchers, such as research conducted by Prabowo, Brahmasari, \& Suryani (2019) regarding the influence of country of origin on the brand image on heavy equipment products in East Java. The research argue that the higher the country of origin, the stronger the brand image of heavy equipment in the mining industry in East Java province.

According to Keegan et al. (2013, p. 340), country of origin is part of the brand image and contributes to brand equity. This theory applies to car products, electronics, fashion, beer, music records, and certain food products. It has been proven in several studies, like Tulipa et al. (2015), conducted a study on the relationship between counties of origin and smartphone brand image in Surabaya. This study prove that the country of origin has a significant relationship with smartphone brand image. Researchers also argue that consumers feel that a country with a good reputation will produce good products so that a good country means a good brand image too.

Based on the theories of previous studies of the relationship between variables country of origin image with the brand image that has been mentioned above, the research hypothesis which is formed as follows:

H1: Country of Origin Image (X1) positively influence Brand Image (X2) towards Nike brand.

\section{Country of Origin Image towards Brand Evaluation}

Brand evaluation is a consumer's emotional response to a brand. When consumers have strong trust in a country, they tend to have superior brand evaluation ratings. It is evidenced in a study conducted by Hien et al., (2019) on the electric household appliance industry. The results state that country of origin has a positive effect on brand evaluation. Researchers state that customers assess the quality and value of electric household appliances products based on the 
image of the country of origin.

Kim et al. (2017) also stated that country of origin image has a positive influence on the brand evaluation of fashion products. Researchers argue that a better country image can lead to higher brand evaluations. Norouzi \& Hosienabadi (2011) argue that a brand's country of origin can influence consumer evaluation. Country of origin can help consumers in the process of considering brand evaluation factors such as value, equity, quality, popularity, and brand satisfaction in their perceptions (Eng et al., 2016; Huang, Wang, \& Cheng, 2020).

Based on the theories of previous studies of the relationship between variables country of origin image with a brand evaluation which has been mentioned above, the research hypothesis which is formed as follows:

H2: Country-of-origin Image (X1) positively influencing Brand Evaluation (X3) towards Nike brand.

\section{Country Image towards Purchase Intention.}

Purchase intention reflects consumer behaviour that is predicted or planned in the future, as well as the possibility that beliefs and behaviour will be translated into purchasing behaviour (Engel et al., 1990; Kim et al., 2017). Consumer confidence in a country will increase purchase intention. A good country of origin image will create a strong purchase intention. Country of origin is used as an indicator of product quality; products made in developed countries are seen as better in quality than products in developing countries (Sharma \& Kaur, 2020). This is in line with the results of research conducted by Hien et al. (2019) that there is consumer confidence in brands originating from developed countries.

Country of origin is one of the extrinsic factors that greatly influence customer's purchase intention. It has been proven by Esmailpour \& Tabrizi (2016) in their research on the influence of country-of-origin image on purchase intention for mobile phone products from Korea and Iran. Based on the results, there was a positive relationship between variables. In this case, consumers pay attention to the country image in deciding on the product. However, according to Keegan et al. (2013, p. 340), a country's manufacturing reputation can change over time. It has been proven in Yunus \& Rashid's (2016) research that there was a change in consumer perceptions of products from China based on previous research findings. The existence of economic growth and technological developments affect consumer perceptions of the country. Their research results state that there is a relationship between country image and purchase intention of mobile phones from China.

Based on the theories of previous studies of the relationship between variables country of origin image with the purchase intention that has been mentioned above, the research hypothesis which is formed as follows:

H3: Country of origin Image (X1) positively influence Purchase Intention (Y1) towards Nike brand.

\section{Brand Image and Purchase Intention}

Keegan et al. (2013, p. 353) argue that a brand is a consumer's thought towards a complex set of images and experiences. Brands are considered to have a very important role for both consumers and companies. Consumers have a role, integrating the experience and information received so that it becomes a perception. This impression is a brand image.

Brand image is a perception of a brand that is reflected in the brand association that consumers hold in their memory (Keller, 2013, p. 72). Keegan et al. (2013, p. 329) also argue that brand image is the overall impression of consumers on advertising, publicity, word of mouth, sales 
staff, packaging, price, and distribution of these products. Therefore, brand image is often used as an extrinsic signal in making purchasing decisions (Richardson, Dick \& Jain, 1994; Bhakar, Bhakar, \& Bhakar, 2013).

Brand image has long been recognized as an important concept in marketing. Creating a positive brand image requires a marketing program that links strong, profitable, and unique associations to a brand in the memory of consumers (Keller, 2013, p. 73). Hien et al. (2019) also emphasized that a good image of a brand will create a strong purchase intention.

Purchase intention can motivate consumers to continue recording an image on their mind. Positive brand image can be the strength of the company to attract consumers to try their products (Prabowo et al., 2019). It has been proven in his research which states that brand image has a significant effect on purchase intention. Researchers argue that the stronger the brand image of a product, the higher the consumer's purchase intention.

The relationship between these variables was also proven in research conducted by Ramadhan \& Muthohar (2019) private label products. Researchers state that the brand plays an important role in the purchase intention process; the higher the brand image will reflect the level of product quality and increase purchase intention.

Based on the theories from previous research regarding the relationship between brand image variables and purchase intention that have been presented above, the research hypothesis is formed as follows:

H4: Brand Image (X2) positively influence Purchase Intention (Y1) towards Nike brand.

\section{Brand Evaluation towards Purchase Intention}

Brand evaluation is one of which the association methods that can measure the brand equity. Sirianni, Bitner, Brown, \& Mandel (2013) define brand evaluation as a general affective assessment of consumers on a brand. Brand evaluation as a whole measures' consumers' responses to a brand such as joy, trust, and desire (Netemeyer et al., 2004; Sirianni et al., 2013). Brand evaluation relies on what consumers remember about a brand because they can recognize the brand through it.

Brand evaluation is a personal opinion formed by consumers based on the performance and association of a brand (Keller, 2013, p. 177). An assessment of a brand in the minds of consumers will produce brand responses \& evaluations, and a positive brand evaluation will generate purchase intention. It was conveyed on the Devita \& Agustini (2019) study that at the evaluation stage, superior brands will form consumers purchase intention.

It is also related to the results of research conducted by Hien et al. (2019), which states that brand evaluation has a positive effect on purchase intention. Researchers emphasize that brand evaluation has an important role in consumers purchase intention. Brands that are highly rated will create a stronger purchase intention.

Based on the theories from previous research regarding the relationship between brand evaluation variables and purchase intention that have been presented above, the research hypothesis is formed as follows:

H5: Brand Evaluation (X3) positively influence Purchase Intention (Y1) towards Nike brand.

The Mediating role of Brand Image in the process by which the Country of origin image influences Customer's Purchase Intention.

Country of origin will reflect the characteristics of a product that will shape the perception of the product in the eyes of consumers. Products offered to consumers will have a label where the 
product comes from so that products with a good country image will have a good perception too. This perception will form a thought process that will shape purchase interest (Moksaoka \& Rahyudah, 2016). This theory has been proven by several researchers regarding the role of brand image in the process of country of origin image influencing customer purchase intention.

Moksaoka et al. (2016) study shows that brand image is able to mediate the influence of country of origin with purchase intention. Hien et al. (2019) have also proven that brand image is a mediator in the process in which country of origin affects customer's purchase intention. Researchers also stated that when the brand image comes from a country that is considered good, the brand image will be better, and consumers will create a stronger purchase intention. This statement is the same as Adenan et al. (2018) which also states that the brand image of a product is likely to be affected if it comes from a well-known country, this process will eventually lead to product evaluation and purchase intention of the product.

Based on the theories from previous research regarding the role of brand image as a mediator in the relationship between the country of origin image variables and purchase intention as stated above, the research hypothesis is formed as follows:

H6: Brand Image (X2) mediates the process by which the Country of origin image (X1) influences the Customer Purchase Intention (Y1) towards Nike brand.

\section{The Mediating role of Brand Evaluation in the process by which the Country-of-origin image influences the Customer's Purchase Intention}

Consumers using the country of origin as an indication of extrinsic rather than intrinsic, especially in the evaluation of new products (Michaelis et al., 2008; Adina, Gabriela, and RoxanaDenisa, 2015). According to Adina et al. (2015), country of origin is an essential factor in influencing consumers' brand evaluation, perceptions and purchasing behaviour. This statement is the same as the opinion of Arora et al. (2016; Huang et al., 2020) that the country of origin image has a considerable influence on the evaluation of the product so that the consumer buying behaviour for the better.

This theory has been proven in the research of Hien et al. (2019), that brand evaluation is a mediator in the process in which country of origin image affects customer's purchase intention. The researcher also explained that when a brand comes from a country that is considered acceptable, consumers will value the brand higher, thus creating a stronger purchase intention.

Based on the theories of previous research on the role of brand image as a mediator in the relationship between variables country of origin image with the purchase intention that has been mentioned above, the research hypothesis which is formed as follows:

H7: Brand Evaluation (X3) mediates the process by which the Country of origin image (X1) influences the Customer Purchase Intention (Y1) towards Nike brand.

\section{RESEARCH METHOD}

This research model is taken from previous research conducted by Nguyen Ngoc Hien, Nguyen Nguyen Phuong, Tung Van Tran, and Le Duc Thang (2019) with the title "The effect of country-of-origin image on purchase intention: The mediating role of brand image and brand evaluation". The study of the effect of country of origin, brand image and brand evaluation on purchase intention based on the theories and hypotheses that has been described above, then the conceptual model proposed by researcher is as follows: 


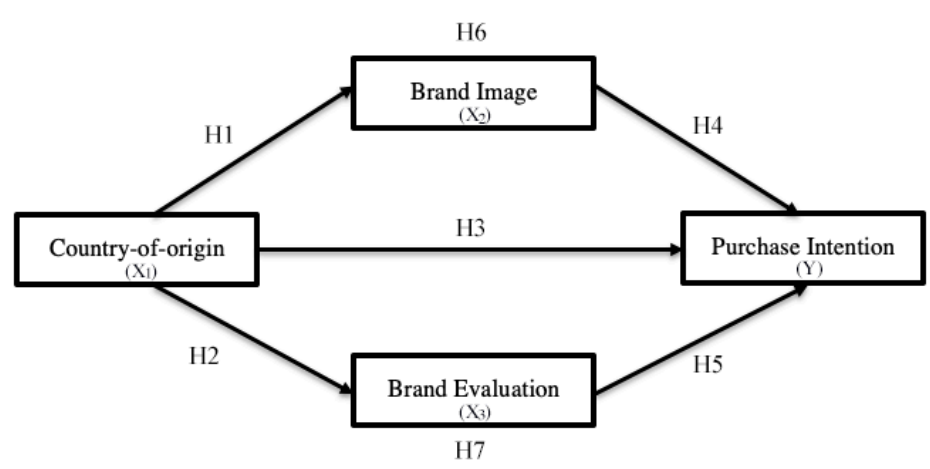

Figure 2.1 Conceptual Model of the research Source: Hien et al. (2019)

A descriptive and inferential study was conducted in this study to test the hypothesis proposed by the researcher, by using sample of 220 respondents, following the theory of Hien et al. (2017) that the number of research indicators must be multiplied by ten. The population used is non-probability with the type of sampling, namely convenience. Respondents must meet the researcher's criteria, such as respondents who are at least 17 years old and domiciled in the Jabodetabek area, then the respondent must at least be familiar with the Nike brand.

In conducting this research, a structured questionnaire was used as an instrument to collect information from respondents. It consists of 20 statements in the form of a Likert scale that allows respondents to express their agreement level. The researcher questionnaire collection was divided into four parts according to the research variables. The data analysis method of this research is PLS-SEM using the SmartPLS application. The validity and reliability of variables used in this study has been tested in the pretest, and the results show that 21 indicators in the pretest are the remaining 20 indicators that will be used in the actual test. The sources of the instruments and indicators of this study are presented in Table 1.

Table 1. Conceptual and Operational Definition

\begin{tabular}{|c|c|c|c|}
\hline Variables & & Conceptual Definition & Operational Definition \\
\hline $\begin{array}{l}\text { Country of } \\
\text { Image }\end{array}$ & )rigin & $\begin{array}{l}\text { Country of origin } \\
\text { image is the belief, } \\
\text { idea, and impression } \\
\text { that a person has about } \\
\text { a country formed from } \\
\text { associations and } \\
\text { informational } \\
\text { indications connected } \\
\text { to a place (Herrero- } \\
\text { Crespo, Gutierrez, } \\
\text { Garcia-Salmones, } \\
\text { 2016). }\end{array}$ & $\begin{array}{l}\text { The country from this brand originates is a } \\
\text { country that is innovative in manufacturing. } \\
\text { The country from this brand originates is a } \\
\text { country that is prestigious. } \\
\text { The country from this brand originates is a } \\
\text { country that has an image of advanced } \\
\text { country } \\
\text { The product quality of this country is high } \\
\text { level. } \\
\text { The product of this country is reliable. }\end{array}$ \\
\hline Brand Image & & Brand image & This brand makes me confidence. \\
\hline
\end{tabular}




\begin{tabular}{|c|c|c|}
\hline & $\begin{array}{l}\text { merupakan persepsi } \\
\text { terhadap suatu merek } \\
\text { yang tercermin dari } \\
\text { asosiasi merek yang } \\
\text { dipegang konsumen } \\
\text { dalam ingatan mereka } \\
\text { (Keller, 2013). }\end{array}$ & $\begin{array}{l}\text { This brand is more popular than the others. } \\
\text { This brand's quality is high. } \\
\text { It is one of the best brands in the industry. } \\
\text { This brand's characteristics can be } \\
\text { distinguished from competitors. } \\
\text { This brand's characteristics are better than } \\
\text { its competitors's ones. }\end{array}$ \\
\hline Brand Evaluation & $\begin{array}{l}\text { Brand evaluation } \\
\text { merupakan penilaian } \\
\text { afektif konsumen } \\
\text { secara umum terhadap } \\
\text { suatu merek (Sirianni, } \\
\text { Bitner, Brown, \& } \\
\text { Mandel, 2013). }\end{array}$ & $\begin{array}{l}\text { I find this brand interesting. } \\
\text { I find this brand good. } \\
\text { I find this brand useful. } \\
\text { I find this brand promising. } \\
\text { I'm attracted to this brand. }\end{array}$ \\
\hline Purchase Intention & $\begin{array}{lr}\begin{array}{l}\text { Purchase intention } \\
\text { merupakan kemauan } \\
\text { konsumen }\end{array} \\
\text { kemungkinan dan } \\
\text { membeli untuk } \\
\text { maupun layanan di } \\
\text { masa depan setelah } \\
\text { evaluasi dilakukan } \\
\text { (MacKenzie et al., } \\
\text { 1986; Laroche \& } \\
\text { Sadokierski, 1994; } \\
\text { Panigara \& } \\
\text { Ratnaningtyas, 2017). }\end{array}$ & $\begin{array}{l}\text { I will consider to buy this brand's product. } \\
\text { I will purchase this brand's product } \\
\text { immediately. } \\
\text { I will purchase this brand's product in the } \\
\text { near future. } \\
\text { I would like to own this brand's product. } \\
\text { I'm confident of purchasing this brand's } \\
\text { product regardless of time. }\end{array}$ \\
\hline
\end{tabular}

\section{RESULTS AND DISCUSSION}

After distributing questionnaires, there were 228 respondents in this study. However, the data that can be used in this study are 220 respondents or about $96.5 \%$. The question on the first page that the researchers asked was the respondent's knowledge of the brand, which consisted of is the respondent familiar with the Nike brand or not, and is the respondent had ever used Nike shoes or not. Furthermore, the analysis of the respondents' background covered gender, age, level of education, occupation and respondents' average monthly income. The profile of respondents is presented in the Table 2 .

Tabel 2 Profile of Respondents

\begin{tabular}{llll}
\hline Demographic Variable & Categories & No. of Respondents & Percentage \\
\hline \multirow{2}{*}{ Gender } & Female & 148 & $67.3 \%$ \\
Age & Male & 72 & 32.7 \\
\hline
\end{tabular}




\begin{tabular}{llll}
$21-25$ & 148 & $67.3 \%$ \\
$26-30$ & 9 & 1 & $4.1 \%$ \\
$31-35$ & - & $0.4 \%$ \\
Above 35 & 78 & $0 \%$ \\
Domicile & Jakarta & 9 & $35.4 \%$ \\
& Bogor & 5 & $4.1 \%$ \\
Depok & 110 & $2.3 \%$ \\
Tangerang & 18 & $50 \%$ \\
Bekasi & 172 & $8.2 \%$ \\
Profession & Student & 12 & $78.2 \%$ \\
& Entrepreneur & 34 & $5.5 \%$ \\
Employment & - & $15.5 \%$ \\
& Homemaker & - & $0 \%$ \\
& Retired & 2 & $0 \%$ \\
& Other & & $0.8 \%$ \\
\hline
\end{tabular}

Source: SmartPLS result.

Table 2 shows that most of the respondents are students, in generation Y. Table 3 below shows the mean values for all variables used in the study.

Table 3. Descriptive Result.

\begin{tabular}{llll}
\hline \multicolumn{2}{l}{ DESCRIPTIVE STATISTICS } & & \\
\hline Variables & Indicators & Mean & Standard Deviation \\
\hline \multirow{2}{*}{ Country of } & COI1 & 4.323 & 0.681 \\
Image (COI) & COI2 & 4.400 & 0.517 \\
& COI4 & 4.355 & 0.682 \\
& COI5 & 4.336 & 0.678 \\
Brand Image (BI) & BI1 & 4.050 & 0.859 \\
& BI2 & 3.932 & 0.991 \\
& BI3 & 4.409 & 0.671 \\
& BI4 & 4.309 & 0.789 \\
& BI6 & 4.382 & 0.674 \\
& BE1 & 4.095 & 0.778 \\
Brand Evaluation (BE) & BE3 & 4.395 & 0.696 \\
& BE4 & 4.405 & 0.643 \\
& BE5 & 4.268 & 0.717 \\
Purchase Intention (PI) & PI1 & 4.295 & 0.762 \\
\hline
\end{tabular}




\begin{tabular}{lll}
\hline PI2 & 4.023 & 0.960 \\
PI3 & 3.255 & 1.268 \\
PI4 & 4.073 & 0.926 \\
PI5 & 3.809 & 1.066 \\
\hline
\end{tabular}

Source: SmartPLS result.

Based on the descriptive results, the country of origin image (COI2) has the highest score with $M=4,400$. Based on this construct, the majority of respondents agreed with the statement that USA is a country that is prestigious. Furthermore, in the Brand image variable (BI3), the score shows $\mathrm{M}=4.409$. It can be assumed that the majority of respondents agreed that the Nike brand has a high quality. In addition, the variable brand evaluation (BE2) shows that $\mathrm{M}=4.405$. This value shows that the majority of respondents agree that Nike is a good brand. and the last on the variable purchase intention (PI1) the value shows $\mathrm{M}=4.223$. The majority of respondents agree that they will consider buying Nike shoes.

The Correlational Analysis can be seen on Table 4 that shows the summary of correlational analysis and the hypotheses test for all variables. First hypothesis, the value shows that there's a correlations between $\mathrm{COI}$ and $\mathrm{BI}$ with the $\mathrm{t}$ value $=7.881, \mathrm{p}$ value $=0.000$. It means that the country of origin image positively influence brand image towards Nike brand. The second hypothesis, the value also shows that there's a correlations between $\mathrm{COI}$ and $\mathrm{BE}$ with the $\mathrm{t}$ value $=9.282, \mathrm{p}$ value $=0.000$. It means that the country of origin image positively influences brand evaluation towards Nike brand. Next, the third hypothesis, the value shows that there's no correlations between $\mathrm{COI}$ and PI with the $\mathrm{t}$ value $=1.118, \mathrm{p}$ value $=0.132$. It means that the country of origin image cannot influence brand evaluation towards Nike brand positively.

Fourth hypothesis, the value shows that there's a correlation between BI and PI with the $\mathrm{t}$ value $=$ 3.009 , $\mathrm{p}$ value $=0.001$. It means that the brand image influence consumers purchase intention towards Nike brand positively. Next, the fifth hypothesis, the value shows that there's a correlation between $\mathrm{BE}$ and PI with the $\mathrm{t}$ value $=4.777, \mathrm{p}$ value $=0.000$. It means that the brand evaluation influence consumers purchase intention towards Nike brand positively.

Thus, the sixth hypothesis, the value shows that there's a correlation between $\mathrm{BI}$ and COI towards the PI with the $t$ value $=2.500, \mathrm{p}$ value $=0.006$. It means that the brand image is able to mediate the process by which the country of origin image influences consumers purchase intention towards Nike brand positively. And the last hypothesis, the value shows that there's a correlation between $\mathrm{BE}$ and $\mathrm{COI}$ towards the PI with the $\mathrm{t}$ value $=4.084$, $\mathrm{p}$ value $=0.000$. It means that the brand evaluation is able to mediate the process by which the country of origin image influences consumers purchase intention towards Nike brand positively.

Tabel 4. Summary of correlational analysis and hypotheses testing

$\begin{array}{lllll}\text { Hypothesis } & \text { Path } & \text { t Statistics } & \text { p-value } \\ & \text { Coefficients } & (>1.645) & (<0.05)\end{array} \quad$ Results $\quad \begin{aligned} & \text { Conclusio } \\ & n\end{aligned}$




\begin{tabular}{lccccc}
$\begin{array}{l}\text { Country of Origin Image } \rightarrow \\
\text { Brand Image }\end{array}$ & 0.522 & 7.881 & 0.000 & $\begin{array}{l}\text { Signific } \\
\text { ant }\end{array}$ & Supported \\
$\begin{array}{l}\text { Country of Origin Image } \rightarrow \\
\text { Brand Evaluation }\end{array}$ & 0.512 & 9.282 & 0.000 & $\begin{array}{l}\text { Signific } \\
\text { ant }\end{array}$ & Supported \\
$\begin{array}{l}\text { Country of Origin Image } \rightarrow \\
\text { Purchase Intention }\end{array}$ & 0.089 & 1.118 & 0.132 & $\begin{array}{l}\text { Not } \\
\text { Signific } \\
\text { ant }\end{array}$ & $\begin{array}{l}\text { Not } \\
\text { Supported }\end{array}$ \\
$\begin{array}{l}\text { Brand Image } \rightarrow \text { Purchase } \\
\text { Intention }\end{array}$ & 0.309 & 3.009 & 0.001 & $\begin{array}{l}\text { Signific } \\
\text { ant }\end{array}$ & Supported \\
$\begin{array}{l}\text { Brand Evaluatio } \rightarrow \\
\text { Purchase Intention }\end{array}$ & 0.382 & 4.777 & 0.000 & $\begin{array}{l}\text { Signific } \\
\text { ant }\end{array}$ & Supported \\
$\begin{array}{l}\text { Country of Origin Image } \rightarrow \\
\text { Brand Image } \rightarrow \text { Purchase } \\
\text { Intention }\end{array}$ & 0.161 & 2.500 & 0.006 & $\begin{array}{l}\text { Signific } \\
\text { ant }\end{array}$ & Supported \\
$\begin{array}{l}\text { Country of Origin Image } \rightarrow \\
\text { Brand } \\
\text { Purchase Intention }\end{array}$ & 0.195 & 4.084 & 0.000 & $\begin{array}{l}\text { Signific } \\
\text { ant }\end{array}$ & Supported \\
\hline
\end{tabular}

Source: SmartPLS result.

The overall findings therefore show a support for a positive relationship between all the hypotheses, except the hypothesis 3 . The positive relationship between country of origin image and brand image is consistent with the study conducted by Tulipa et al. (2015), Suria et al. (2016), Sulistyawati et al. (2018), Prabowo et al. (2019), and Hien et al. (2019), which states that the country of origin image has a significant effect on brand image. On the other hand, a significant relationship that exists between country of origin image and brand evaluation is also consistent with several previous researchers, Kim et al. (2017) and Hien et al. (2019) who stated that country of origin image has a significant effect on brand evaluation. Next, a negative relationship between country of origin image and purchase intention is supported by Bhakar et al. (2013) and Le et al. (2017) study, which states that there is no relationship between country of origin and purchase intention.

However, result of the fourth hypothesis is supported by previous studies, Tulipa et al. (2015), Prabowo et al. (2019), and Ramadhan et al. (2019), which states that brand image significantly affects purchase intention. Likewise, the result of fifth hypothesis also supported by previous research, Kim et al. (2017) and Hien et al. (2019), which states that brand evaluation significantly affects purchase intention.

Next, the sixth hypothesis, the results on this study supported by by previous studies, Haque et al. (2015), Moksaoka et al. (2016), Hien et al. (2019), and Sharaswati et al. (2020), which states that brand image is able to mediate the relationship between country of origin image and purchase 
intention. And the last one, the seventh hypothesis, the finding is supported by previous research conducted by Hien et al. (2019), which states that brand evaluation mediates positively in the process by which country of origin image affects purchase intention.

\section{CONCLUSION}

The main objective of this study was to investigate the perceptions of Indonesian consumers towards Nike brands. This study also found how country of origin image, brand image, and brand evaluation contributed to the intention of Indonesian in decision making for purchases.

Descriptively, majority of the respondents highly agreed with most of the statements that represent the variables in this study. The results showed that all the independent variables in this study had an effect on consumer buying interest towards the Nike brand, so that the objectives of this study were fulfilled. Also, most of the research hypotheses can be accepted, except for the third hypothesis. It was showed that country of origin image statistically did not influence purchase intention positively. Country of origin image have to mediated by brand image and brand evaluation to influences the purchase intentions.

For further research, it can be taken from a more diverse range of respondents as the research sample to get a broader perspective. It can also consider other factors as independent variables to analyze factors that can influence consumer buying interest, both internal and external.

\section{REFERENCES}

Adenan, M. A., Ali, J. K., \& Rahman, D. H. (2018). Country of Origin, Brand Image and High Involvement Product towards Customer Purchase Intention: Empirical evidence of east malaysian consumer. Jurnal Manajemen dan Kewirausahaan 20(1), 63-72.

Adina, C., Gabriela, C., \& Roxana-Denisa, S. (2015). Country-of-origin Effecys on Perceived Brand Positioning. Procedia Economics and Finance 23, 422-427.

Bhakar, S. S., Bhakar, S., \& Bhakar, S. (2013). Relationship between Country of Origin, Brand Image and Customer Purchase Intention. Far East Journal of Psychology and Business 10(2),

Devita, E. M., \& Agustini, M. H. (2019). Country of Origin and Brand Image on Purchase Decision of South Korean Cosmetic Etude House . Journal of Management and Business Environment 1(1), 5570.

Erdogan, Senem, \& Onur. (2017). The Influence of Country of Origin on Brand Image and Brand Attitudes: an Empirical Study on Turkey. Journal of Business and Science 5(2), 89-103.

Esmailpour, H., \& Tabrizi, P. K. (2016). The Effect of Country of Origin and Product Evaluation on Purchase Intention. Case Studies Journal 5(12), 80-85, 25-47.

Hien, N. N., Phuong, N. N., Tran, T. V., \& Thang, L. D. (2019). The effect of country-of-origin image on purchase intention: The mediating role of brand image and brand evaluation. Management science letters, 1205-1212.

Huang, K.-P., Wang, K. Y., \& Cheng, S. (2020). Brand Evaluation, Animosity, Ethnocentrism and Purchase Intention: A Country of Origin Perspective. International Journal of Organizational Innovation, 80-88.

Karamoy, H., \& Tulung, J. E. (2020). The Effect Of Banking Risk On Indonesian Regional Development Bank. Banks and Bank Systems, 15(2), 130-137

Karamoy, H., \& Tulung, J. E. (2020). The Effect Of Financial Performance And Corporate Governance To Stock Price In Non-Bank Financial Industry. Corporate Ownership \& Control, 17(2), 97-103.

Keegan, W., \& Green, M. (2013). Global Marketing (7 ed.). Upper Saddle River, New Jersey: Pearson.

Keller, K. L. (2013). Strategic Brand Management. Essex: Pearson Education Limited.

Kim, N., Chun, E., \& Ko, E. (2017). Country of origin effects on brand image, brand evaluation, and purchase intention. International $\mathrm{m}=$ marketing review Vol. 34 No. 2, 254-271. 
Kusuma, H. (2019, May 15). Sepanjang April RI Kebanjiran Impor Sepatu Lari. Retrieved from Detik Finance:https://finance.detik.com/berita-ekonomi-bisnis/d-4550358/sepanjang-april-ri-kebanjiranimpor-sepatu-lari

Lew, S., \& Sulaiman, Z. (2014). Consumer Purchase Intention toward Products Made in Malaysia vs. Made in China: A Conceptual Paper. Procedia Social and Behavioral Sciences 130, 37-45.

Mojambo, G. A., Tulung, J. E., \& Saerang, R. T. (2020). The Influence of Top Management Team (TMT) Characteristics Toward Indonesian Banks Financial Performance During The Digital Era (20142018). JMBI UNSRAT (Jurnal Ilmiah Manajemen Bisnis dan Inovasi Universitas Sam Ratulangi)., 7(1).

Moksaoka, I. W., \& Rahyudah, I. (2016). Peran Brand Image dalam Memediasi Country of Origin terhadap Purchase Intention. E-Journal Manajemen Unud 5(3), 1690-1716.

Norouzi, A., \& Hosienabadi, B. F. (2011). The Effects of Brand's Country-of-Origin Image on The Formation of Brand Equity. Australian Journal of Basic and Applied Sciences 5(12), 766-770.

Panigara, G., \& Ratnaningtyas, S. (2017). Factor influence purchase intention towards hairstyling industry in Bandung. Journal of Innovation, Business and Entrepreneurship 2 (1), 77-85.

Prabowo, P. K., Brahmasari, I. A., \& Suryani, T. (2019). The Effect of Country of Origin on Brand Image, Perceived Quality, and Purchase Intention of Hydraulic Excavator for Limestone Quarry in East Java Indonesia. Archives of Business Research 7(12), 83-98.

Ramadhan, M. D., \& Muthohar, M. (2019). The influence of perceived price, perceived quality, brand image, and store image on the purchase intention of Hypermart private label. Advances in social science, education and humanities research, 140-143.

Richter, F. (2020, April 21). Nike still on Top of the Sneaker World. Retrieved from Statista.com: https://www.statista.com/chart/13470/athletic-footwear-sales/

Schiffman, L. G., \& Wisenblit, J. L. (2015). Consumer Behavior. Essex, England: Pearson Education Limited.

Sharma, A., \& Kaur, D. (2020). The Effect of Country of origin on Consumers Purchase Intention. International Journal of Creative Research thoughts, 104-109.

Sirianni, N. J., Bitner, M. J., Brown, S. W., \& Mandel, N. (2013). Branded Service Encounters: Strategically Aligning Empioyee Behavior with the Brand Positioning. Journal of Marketing Vol.77, 108-123.

Sullivan, D. P., Radebaugh, H. L., \& Daniels, D. J. (2015). International Business Environments and Operations. Essex, England: Pearson Education Limited.

Top Brand Award. (2020, November 8th). Top Brand Index Nike. Retrieved from topbrand-award.com: https://www.topbrand-award.com/top-brand-index/?tbi find=nike

Top Brand Award. (2020, September 29). Top Brand Index of Sport Shoes in Indonesia. Retrieved from Top Brand Award: https://www.topbrand-award.com/top-brand-index/?tbi find=nike

Tulipa, D., \& Muljani, N. (2015). The country of origin and brand image effect on purchase intention of smartphone in Surabaya - Indonesia. Mediterranean Journal of Social Sciences 6(5), 64-70.

Yaqoob, Q. T. (2018). Impact of Facebook Advertisments on Purchase Intentions of Mobile Facebook Users: Investigating the Moderating Role of Brand Origin and Perceived Product Value. Dissertation of Economics and Management, 34.

Yulistara, A. (2018). 60\% Orang Indonesia Pilih Beli Produk Asing Ketimbang Lokal. Jakarta: CNBC Indonesia. Retrieved from : https://www.cnbcindonesia.com/lifestyle/20180326194751-33-8635/60orang-indonesia-pilih-beli-produk-asing-ketimbang-lokal

Yunus, N. S., \& Rashid, W. E. (2016). The Influence of Country-of-origin on Consumer Purchase Intention: The Mobile Phones Brand from China. Procedia Economics and Finance 37, 343-349. 